UNIO - EU Law Journal. Vol. 6, No. 2, July 2020, pp 3-14.

®2020 Centre of Studies in European Union Law

School of Law - University of Minho

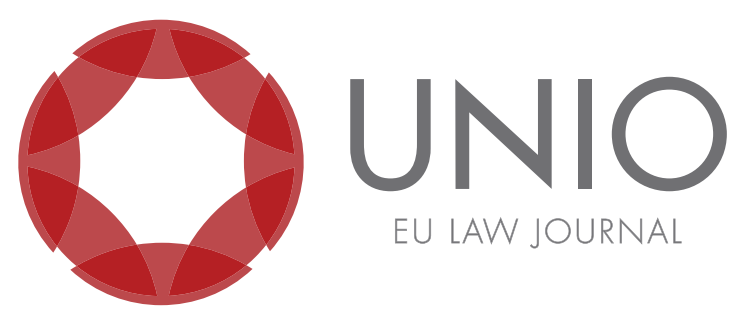

\title{
COVID-19-related travel restrictions and mobility rights: A test for international human rights standards and EU citizenship
}

\author{
Patrícia Jerónimo*
}

ABSTRACT: While there is still much that we do not know about COVID-19, it has by now become clear that, far from being "the great equalizer" or a catalyst for international solidarity, the disease is disproportionately impacting the poor and the most vulnerable, fuelling nationalist and xenophobic sentiments, and prompting a resurgence of borders and mobility restrictions all over the globe. Many States have resorted to emergency measures and/ or derogated from their international buman rights obligations to enjoy more leeway when restricting individual freedoms in their "war" against the pandemic. Mobility rights are among the most impacted by the COVID-19-related measures, with lockdowns, mandatory quarantines, and travel bans. The article discusses the extent to which the EU Member States' use of their international and EU law prerogatives to close their borders on public health grounds can be considered to have breached international human rights standards and hindered EU citizenship.

KEYWORDS: COVID-19 - Nationalism - mobility rights - EU citizenship.

\footnotetext{
*Associate Professor at the Law School of the University of Minho. Director of the Research Centre for Justice and Governance (JusGov).

This article is based on and expands a post published by Official blog Unio, on 20 April 2020, under the title "COVID-19-Nationalism and its toll on citizenship and mobility rights in the European Union." The research was conducted in the context of the FCT funded project InclusiveCourts, under grant PTDC/DIR-OUT/28229/2017.
} 


\section{Introduction: COVID-19-Nationalism and the resurgence of borders}

When the first cases of the new coronavirus infections started to appear outside of China, in January 2020, COVID-19 was perceived to be a "rich man's disease," as it seemed to affect mostly wealthy travellers returning from business trips or short stays abroad for studies or tourism. It took no time for the virus to spread from the affluent to the poor, but the oddity of facing a virus that apparently knew no social boundaries and spared no one led to the view that COVID-19 was "the great equalizer."1 This assumption was soon proved wrong, as the virus and many of the measures adopted to fight it were shown to disproportionately impact the poor and the most vulnerable - including racial/ethnic minorities, women, immigrants and asylum seekers ${ }^{2}-$, contributing to the amplification of existing socio-economic inequalities. Similarly, the expectation that the shared global experience ${ }^{3}$ of the pandemic would inspire solidarity across class, race, religious and national divides also proved to be largely unfounded. Since the start of the pandemic, there have been numerous reports of racist and xenophobic incidents linked to COVID-19, first directed against Chinese nationals and people perceived as of Asian origin, then extended to African migrants, asylum seekers, Muslims, Roma communities, and foreigners in general. ${ }^{4}$ As for the States, their immediate reaction was to close borders, adopt protectionist measures and compete against each other for medical supplies and personnel. ${ }^{5}$

It would seem obvious that the global nature of the COVID-19 pandemic requires international collaboration to mount an effective response, yet unilateralism and selfishness have been pervasive, prompting talk of deglobalisation and raising concerns that the fight against the virus will revive and embolden nationalism in its ugliest forms. In their discussion of the correlation between the pandemic and nationalism, Eric Taylor Woods et al. consider it likely that COVID-19 will work to erode global institutions and to strengthen the (powerful) Nation States, while contributing to the intensification of existing ethnic and national cleavages. ${ }^{6}$ There is also fear that national governments might abuse emergency powers to increase control over their populations and to elude parliamentary and judicial oversight, and that the health

\footnotetext{
${ }^{1}$ See e.g. Stephen A. Mein, "COVID-19 and health disparities: The reality of 'the great equalizer"', Journal of General Internal Medicine, v. 35, no. 8 (August 2020): 2439-2440.

2 As pointed out by several international human rights agencies. See e.g. UN Committee on the Elimination of Racial Discrimination, Statement on the coronavirus (COVID-19) pandemic and its implications under the International Convention on the Elimination of All Forms of Racial Discrimination, August 7, 2020; UN Committee on the Elimination of Discrimination against Women, Guidance Note on CEDAW and COVID-19, April 22, 2020; UN Committee on Migrant Workers and UN Special Rapporteur on the Human Rights of Migrants, Joint Guidance Note on the Impacts of the COVID-19 Pandemic on the Human Rights of Migrants, May 26, 2020; all available at https://www.ohchr.org/EN/HRBodies/ Pages/COVID-19-and-TreatyBodies.aspx, accessed September 21, 2020.

${ }^{3}$ See Florian Bieber, "Global nationalism in times of the COVID-19 pandemic", Nationalities Papers (2020): 1.

${ }^{4}$ See e.g. "Bulletin \# 1 Coronavirus Pandemic in the EU: Fundamental Rights Implications", FRA, April 2020, available at https://fra.europa.eu/sites/default/files/fra_uploads/fra-2020-coronaviruspandemic-eu-bulletin-1_en.pdf, accessed April 13, 2020.

${ }^{5}$ See Peter Goodman et al., "A new front for nationalism: the global battle against a virus", The New York Times, April 10, 2020, available at https://www.nytimes.com/2020/04/10/business/ coronavirus-vaccine-nationalism.html, accessed April 11, 2020.

${ }^{6}$ See Eric Taylor Woods et al., "COVID-19, nationalism, and the politics of crisis: A scholarly exchange", Nations and Nationalism (2020): 3.
} 
crisis will contribute to accelerate the backslide of democracies into authoritarianism. ${ }^{7}$ States are certainly centre-stage in the "war" against the virus and, in their defence of national interest/security, have been able to restrict individual liberty and privacy in unprecedented ways.

There is no clearer sign of the return to the State than the resurgence of national borders. When it was announced that we were facing a global pandemic, States all over the world rushed to close their borders and impose sweeping travel restrictions, with some adopting blatantly discriminatory practices, such as barring access to foreigners solely on the basis of their nationality and irrespective of whether or not they had been physically present in a region affected by the virus. ${ }^{8}$ Even when based on place of departure, travel bans are known to be mostly "security theatre", since they are ultimately ineffective in blocking the spread of the virus, ${ }^{9}$ but their political appeal is enormous and they have been used widely. It may be said that, by rushing to close borders, States were first and foremost seeking to fulfil their obligation to protect the lives and health of their populations. It is clear however that many national governments seized the opportunity offered by the virus scare to push their antiimmigration agendas and regain border control. Good or bad intentions aside, the fact is that the travel restrictions imposed to address COVID-19 have had profound implications for the lives of millions of people and, as discussed in the next section, their compliance with international human rights law is much disputed, even if States enjoy ample prerogatives to control who enters their territories.

\section{Travel restrictions and international human rights law}

States' entitlement to control immigration, while challenged for many decades and from many quarters, is still generally recognised in the practice of the international system. ${ }^{10}$ The 1966 International Covenant on Civil and Political Rights does not recognise the right of aliens to enter or reside in the territory of a State party. Under Article 12 of the Covenant, liberty of movement is only recognised to those who are already lawfully within the territory of a State, and States are free to establish the criteria for lawful admission.

The UN Human Rights Committee has held that there may be circumstances in which an alien may enjoy the protection of the Covenant in relation to entry into a territory, as will be the case for instance when considerations of non-discrimination arise. ${ }^{11}$ Travel bans based solely on nationality, as those reported in Hungary and Iraq for example, may well be a case in point. Also problematic in light of Article 12 is the refusal to admit foreigners who are legal residents in the country, as was reported to

\footnotetext{
${ }^{7}$ See Yvonne Tew, "Constitutionalism in the time of corona", International Journal of Constitutional Law Blog, June 10, 2020, available at http://www.iconnectblog.com/2020/06/constitutionalism-inthe-time-of-corona/, accessed June 11, 2020.

${ }^{8}$ That was the case with Hungary and Iraq, among others. See Jelena Dzankic and Lorenzo Piccoli, "Coronavirus: Citizenship infected", GlobalCIT blog, March 13, 2020, available at https:/ /globalcit.eu/ coronavirus-citizenship-infected/, accessed September 23, 2020.

9 See Yasmeen Serhan and Timothy McLaughlin, "The other problematic outbreak", The Atlantic, March 13, 2020, available at https://www.theatlantic.com/international/archive/2020/03/ coronavirus-covid19-xenophobia-racism/607816/, accessed April 13, 2020.

${ }^{10}$ See Joseph H. Carens, "Who should get in? The ethics of immigration admissions", Ethics \& International Affairs, v. 17, no. 1 (April 2003): 1.

${ }^{11}$ Human Rights Committee, General Comment no. 15: The Position of Aliens under the Covenant, 1986, S 5, available at https://www.refworld.org/pdfid/45139acfc.pdf, accessed April 14, 2020.
} 
happen in Ecuador and Guatemala, and the refusal to allow anyone (foreigners and nationals alike) to leave the country, as reported in Namibia and the Czech Republic. ${ }^{12}$ Both the right to liberty of movement and the right to leave the country can be restricted by States, under Article 12(3), provided that restrictions are prescribed by law, are necessary to protect national security, public order, public health or morals or the rights and freedoms of others, and are consistent with the other rights recognised in the Covenant, i.e. that they meet the requirements of legality, necessity and proportionality. ${ }^{13}$ States are only obliged to admit their own nationals, per Article 12(4) of the Covenant, an obligation arguably breached by Cyprus when it barred entry to its own nationals returning from hotspots abroad in the first days of the outbreak, ${ }^{14}$ and by Namibia when it made admission of its own nationals conditional on their performing missions that were critical to national interest. ${ }^{15}$ It should be pointed out however that Article 12(4) uses the qualifier "arbitrarily" - "no one shall be arbitrarily deprived of the right to enter bis own country" -, which suggests that there may be instances in which even nationals may be lawfully barred at the border, a possibility that the Human Rights Committee considers unlikely but does not dismiss entirely. ${ }^{16}$

This means that - outside of the cases of blatant discrimination and disproportionality - the travel restrictions imposed to address the COVID-19 health crisis may well be able to pass muster if brought to the attention of the Human Rights Committee by interstate or individual communications under the relevant provisions of the Covenant and its Optional Protocol. Several States party to the Covenant have nevertheless opted to pre-empt any future reprimands and used their prerogative under Article 4 to notify the UN Secretary-General that they were temporarily derogating from their obligations under Article 12, among other provisions of the Covenant. ${ }^{17}$ The move by States to derogate from their international human rights obligations in times of crisis may be seen as ominous, but it has been lauded as an act of transparency and as a safeguard against the risk of normalising the exceptional. ${ }^{18}$ In April 2020, the Human Rights Committee called on all States which had taken emergency measures in connection with the COVID-19 pandemic to notify the Secretary-General of the derogations without delay. ${ }^{19}$ Invoking Article 4 does not give States carte blanche to do as they please There are a number of requirements to be met: (a) there must be an official proclamation of a state of emergency; (b) the Secretary-General must be notified and

\footnotetext{
${ }^{12}$ Andrea Salcedo, Sanam Yar and Gina Cherelus, "Coronavirus travel restrictions, across the globe", The New York Times, July 16, 2020, https://www.nytimes.com/article/coronavirus-travel-restrictions. html, accessed September 24, 2020.

${ }^{13}$ Human Rights Committee, General Comment no. 27: Freedom of Movement (Article 12), 1999,

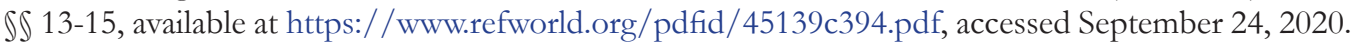
${ }^{14}$ See Cyprus' Country Report for FRA's comparative study on the Coronavirus COVID-19 outbreak in the EU, pp. 5-6, available at https://fra.europa.eu/sites/default/files/fra_uploads/cyprus-reportcovid-19-april-2020_en.pdf, accessed April 14, 2020.

${ }^{15}$ Andrea Salcedo, Sanam Yar and Gina Cherelus, "Coronavirus travel restrictions".

${ }^{16}$ Human Rights Committee, General Comment no. 27, \ 21.

17 At time of writing, these are: Argentina, Armenia, Chile, Colombia, Ecuador, El Salvador, Estonia, Ethiopia, Georgia, Guatemala, Kyrgyzstan, Latvia, Moldova, Palestine, Peru, Romania, San Marino, and Thailand. Information available at https://datastudio.google.com/u/0/ reporting/1sHT8quopdfavCvSDk7t-zvqKIS0Ljiu0/page/dHMKB, accessed September 24, 2020.

${ }^{18}$ See e.g. Giulia Borgna, "Uncharted waters: Navigating through extradition proceedings in the face of the coronavirus pandemic", Giurisprudenza Penale, no. 5 (2020): 15.

${ }^{19}$ Human Rights Committee, Statement on derogations from the Covenant in connection with the COVID-19 pandemic, CCPR/C/128/2, April 30, 2020, \1, available at https://www.ohchr.org/ Documents/HRBodies/CCPR/COVIDstatementEN.pdf, accessed September 24, 2020.
} 
provided full information about the derogating measures taken and a clear explanation of the reasons for taking them; (c) the derogations must be strictly necessary and proportional, i.e. limited in duration, geographical coverage and material scope, as far as possible; (d) the measures taken must be in conformity with other international obligations; (e) the measures taken must not involve discrimination on the grounds of race, colour, sex, language, religion or social origin; and (f) certain non-derogable rights, such as the right to life and the prohibition of torture or cruel, inhuman or degrading treatment or punishment, are off limits. It is worth noting that, while Article 12 was the provision that States consistently included in their derogation notices, the Human Rights Committee does not consider it necessary to derogate from it, since this provision already allows restrictions. The Committee actually advises States that they should not derogate from Covenant rights or rely on a derogation made when they are able to attain their public health or other public policy objectives by invoking the possibility to restrict certain rights, such as Article $12 .{ }^{20}$

If we move from the UN to the Council of Europe framework, the picture will not change dramatically, even though some of the rights have more bite and there are some promising developments in the case law of the European Court of Human Rights. Like the UN Covenant, the European Convention on Human Rights (ECHR) and its Protocols do not recognise the right of aliens to enter or reside in the territory of a State party, and expressly allow restrictions to the freedom of movement of those lawfully within the territory of a State for the protection of health [Article 2 (3) of Protocol No. 4]. However, State nationals enjoy a stronger right of admission, since Article 3 of Protocol No. 4 prescribes that no one shall be expelled from the territory of the State of which he is a national nor be deprived of the right to enter the territory of that State, and foreigners benefit from the explicit prohibition of collective expulsions (Article 4 of Protocol No. 4).

The European Court of Human Rights, in spite of its frequent reminders that States have the right to control entry, residence and expulsion of non-nationals, ${ }^{21}$ has come to set some limits on this right, by holding States responsible when their decisions to refuse entry or to expel foreigners are deemed to place foreigners at risk of being killed or subject to torture (in breach of Articles 2 and 3 of the Convention) or hinder the foreigners' right to private and/or family life (in breach of Article 8). ${ }^{22}$ The Court has also been critical of push-backs at sea, having held Italy responsible for breach of Article 3 of the Convention and Article 4 of Protocol No. 4, after the Italian coastguard summarily returned a group of about 200 migrants to Libya without giving them the opportunity to apply for asylum. ${ }^{23}$

Presumably to prevent equally severe assessments of their emergency measures, a few States - Albania, Armenia, Estonia, Georgia, Latvia, North Macedonia, Romania, San Marino and Serbia - made use of the derogation clause in Article 15 of the ECHR, which has a similar wording to that of Article 4 of the UN Covenant mentioned earlier. ${ }^{24}$ Except for Georgia and Serbia, all States have in the meantime withdrawn their

\footnotetext{
${ }^{20}$ Human Rights Committee, Statement on derogations, $\ 2$.

${ }^{21}$ See e.g. Moustaquim v. Belgium, no. 12313/86, \43, February 18, 1991.

${ }^{22}$ See e.g. Mubilanzila Mayek a and Kaniki Mitunga v. Belgium, no. 13178/03, October 12, 2006; Sharifi and

Others v. Italy and Greece, no. 16643/09, October 21, 2014; M. A. and Others v. Lithuania, no. 59793/17,

December 11, 2018.

${ }^{23}$ See Hirsi Jamaa and Others v. Italy [GC], no. 27765/09, February 23, 2012.

${ }^{24}$ There must be a public emergency threatening the life of the nation; the measures derogating from Convention obligations must be limited to what is strictly required by the exigencies of the situation;
} 
derogations. ${ }^{25}$ The Court retains, in any case, the power to assess if the States complied with the requirements of Article 15, namely whether the emergency measures adopted to address the pandemic were strictly required by the exigencies of the situation. ${ }^{26}$

It will take some time before we have a ruling from the Court on any of the measures being taken in the context of the COVID-19 pandemic. ${ }^{27}$ The Court rejected a request filed by Maltese NGO Repubblika for an interim measure, under Article 39 of the Rules of the Court, consisting of ordering that the Maltese and the Italian Governments "reverse their declarations to the effect that their ports are closed/or their countries not places of safety, thus preventing the rescue and disembarkation of immigrants at sea due to Covid-19 circumstances." 28 Nothing very surprising given the Court's parsimonious use of interim measures. ${ }^{29}$ Meanwhile, the Court is looking into the risk of infection by the new coronavirus in the case of Hafeer v. the United Kingdom, ${ }^{30}$ which concerns the extradition to the United States of a sixty-year-old man with several health issues. In its communication of the application, the Court asked the UK Government whether, having particular regard to the ongoing COVID-19 pandemic, there would be a real risk of a breach of Article 3 of the ECHR if the applicant were to be extradited, given the conditions of detention he would face on arrival. Mutatis mutandis, the same can come to be asked about the health risks incurred by individuals as a consequence of a State's decision to deport them to a coronavirus hotspot. The Court's assessment of whether the risk of infection amounts to ill-treatment for purposes of Article 3 of the ECHR will very much depend on the evolution of the epidemiologic situation in the country where the applicant is sent to, which can change very rapidly and be unforeseeable by States' authorities at the time of the decision to extradite or to expel..$^{31}$ It is not unlikely that the Court will be amenable to the States' arguments that they did the best that they could to fulfil their Convention obligations under these most trying circumstances. Strict scrutiny of the necessity and proportionality of the measures taken by States to contain the virus, while required in theory, will prove difficult in practice, given the unprecedented scale and severity of the health crisis, and the ongoing scientific

the measures must not be inconsistent with the State's other obligations under international law; no derogation is allowed for Articles 2 (except for deaths resulting from lawful acts of war), 3, 4(1) and 7; States must keep the Secretary General fully informed of the measures taken and the reasons therefor, as well as of when the measures cease to operate.

${ }^{25}$ Information available at https://www.coe.int/en/web/conventions/full-list/-/conventions/treaty/005/declarations, accessed September 25, 2020.

${ }^{26}$ See Giulia Borgna, "Uncharted waters", 15.

${ }^{27}$ The estimate making the rounds points to five or six years. See Kanstantsin Dzehtsiarou, "COVID-19 and the European Convention on Human Rights", Strasbourg Observers blog, March 27, 2020, available at https://strasbourgobservers.com/2020/03/27/covid-19-and-the-european-convention-on-humanrights/, accessed September 17, 2020.

${ }^{28}$ As pointed out by the Prime Minister of Malta, Robert Abela, in his exchange of May 2020 with the Council of Europe Commissioner for Human Rights, a propos Malta's handling of the situation of migrants in distress at sea. The exchange is available at https://www.coe.int/en/web/commissioner/-/ commissioner-urges-malta-to-meet-its-obligations-to-save-lives-at-sea-ensure-prompt-and-safedisembarkation-and-investigate-allegations-of-delay-or-no, accessed September 24, 2020.

${ }^{29}$ See Kanstantsin Dzehtsiarou, "What can the European Court of Human Rights do in the time of crisis?", Strasbourg Observers blog, April 14, 2020, available at https://strasbourgobservers. com/2020/04/14/what-can-the-european-court-of-human-rights-do-in-the-time-of-crisis/, accessed September 24, 2020.

${ }^{30}$ Application no. 14198/20, lodged on March 19, 2020. Information available at https://hudoc.echr. coe.int/eng\#\{\%22itemid\%22:[\%22001-202335\%22]\}, accessed September 24, 2020.

${ }^{31}$ See Giulia Borgna, "Uncharted waters", 9. 
uncertainty as to the most effective ways to handle it. This does not mean, of course, that all bets are off. As noted by Kanstantsin Dzehtsiarou, while the emergency may be able to justify many things and even lead to a decrease in the level of protection afforded by the ECHR, it will not justify just anything. ${ }^{32}$ In what concerns mobility rights, there can certainly be no justification for collective expulsions, for the disregard of the principle of non-refoulement or for blatantly discriminatory restrictions to freedom of movement (e.g. on the basis of race, colour, national origin or association with a national minority).

\section{Travel restrictions at internal and external borders in the European Union}

The States' rush to barricade themselves behind national borders was particularly disheartening in the European Union, given that freedom of movement has been at the centre of the European integration project from the very start and that the lifting of internal border controls in the Schengen Area has been heralded as one of the bloc's greatest achievements. Intra-European solidarity was nowhere in sight when, starting on March 11, 2020, Austria and other Schengen States unilaterally reintroduced border controls at their land and air borders, in rapid succession, ${ }^{33}$ leaving many EU citizens stranded after being denied admission in Italy, Hungary, Croatia and the Czech Republic, to name a few. ${ }^{34}$ The European Commission's initial response was hesitant, and when it finally stepped up with a plan to ensure a coordinated approach at EU level, not only did it not challenge the Member States' justification for reintroducing internal borders, but it used the same public health rationale (i.e. slow down the spread of the virus and respond to healthcare needs) to argue for the need to impose restrictions at Schengen external borders, by recommending that the Schengen Member States and Associated States should adopt a coordinated decision to impose a temporary restriction on non-essential travel from third countries into the EU+ area, for an initial period of 30 days ${ }^{35}$ a plan endorsed by the European Council, on March 17, 2020.

\footnotetext{
${ }^{32}$ See Kanstantsin Dzehtsiarou, "COVID-19 and the European Convention on Human Rights".

${ }^{33}$ By the end of March, fifteen Schengen States had reintroduced border checks at their national borders. These were: Austria, Hungary, Czech Republic, Switzerland, Denmark, Lithuania, Norway, Poland, Germany, Spain, Finland, Portugal, Estonia, Belgian, France. For a detailed chronology, see Sergio Carrera and Ngo Chun Luk, "Love thy neighbour? Coronavirus politics and their impact on EU freedoms and rule of law in the Schengen Area", CEPS Paper in Liberty and Security in Europe, no. 2020-04 (April 2020): 3-5.

34 "Schengen Area in the brink of suspension: what could be the consequences", Schengenvisainfo, March 25, 2020, https://www.schengenvisainfo.com/news/schengen-area-in-the-brink-of-suspension-what-could-be-the-consequences/, accessed April 14, 2020.

${ }^{35}$ Communication from the Commission to the European Parliament, the European Council and the Council COVID-19: Temporary Restriction on Non-Essential Travel to the EU, COM(2020) 115 final, 16.3.2020. The 30-days period was first extended until May 15 [Communication from the Commission on the assessment of the application of the temporary restriction on non-essential travel to the EU, $\operatorname{COM}(2020) 148$ final, 8.4.2020], and later until June 15 [Communication from the Commission to the European Parliament, the European Council and the Council on the second assessment of the application of the temporary restriction on non-essential travel to the EU, COM(2020) 222 final, 8.5.2020] and June 30 [Communication from the Commission to the European Parliament, the European Council and the Council on the third assessment of the application of the temporary restriction on non-essential travel to the EU, $\operatorname{COM}(2020) 399$ final, 11.6.2020]. In its June 11 communication, the Commission put forward an approach for a gradual and coordinated phasing out of the travel restrictions at Schengen external borders and invited the Council to act with a view to the adoption of a concrete coordinated approach on the list of countries for which travel restrictions could be lifted as of July $1^{\text {st }}, 2020$. On June
} 
EU law sets the most far reaching limitations on the right of States to control their borders, but even here, States retain the prerogative to bar access to their territories on a number of grounds. The temporary reintroduction of border controls at internal borders is allowed by Articles 25 and ff. of the Schengen Borders Code, ${ }^{36}$ and the restriction of freedom of movement of EU citizens from other Member States is allowed by Articles 27 and ff. of Directive 2004/38/EC. ${ }^{37}$

Both the Code and the Directive phrase their provisions narrowly. The reintroduction of internal borders is a measure of last resort, for exceptional circumstances when there is a serious threat to public policy or internal security. It must be of short duration (although it can extend up to two years) ${ }^{38}$ and be limited to what is strictly necessary to respond to the serious threat. The assessment of the proportionality of the measure in relation to the threat must consider inter alia the likely impact of the measure on free movement of persons within the area. The restriction of the freedom of movement of Union citizens is only possible on grounds of public policy, public security, or public health. For the restriction to be imposed on the first two grounds, the individual concerned must represent a genuine, present and sufficiently serious threat affecting one of the fundamental interests of society, and the restriction must comply with the principle of proportionality. For the restriction to be imposed on public health grounds, it is necessary that the disease justifying it has epidemic potential as defined by the relevant instruments of the WHO or is an infectious disease or a contagious parasitic disease which is the subject of protection provisions applying to nationals of the host Member State. ${ }^{39}$ Even though the treatment of the health crisis as an internal security threat is contested, ${ }^{40}$ the magnitude of the COVID-19 pandemic is such that EU Member States will likely have no trouble in making a case for the necessity of their restrictive border measures. Less straightforward will be to assess whether these measures are proportionate, given the evolving and sometimes conflicting medical evidence about the best way

30, the Council adopted the Recommendation on the temporary restriction on non-essential travel into the EU and the possible lifting of such restriction, 2020/0134(NLE), which indicated that the list of third-countries for which restrictions were lifted would be revised every two weeks.

${ }^{36}$ Regulation (EU) 2016/399 of the European Parliament and of the Council of 9 March 2016 on a Union Code on the rules governing the movement of persons across borders (Schengen Borders Code), OJ L 77, 23.3.2016.

${ }^{37}$ Directive 2004/38/EC of the European Parliament and of the Council of 29 April 2004 on the right of citizens of the Union and their family members to move and reside freely within the territory of the Member States amending Regulation (EEC) no. 1612/68 and repealing Directives 64/221/ EEC, 68/360/EEC, 72/194/EEC, 73/148/EEC, 75/34/EEC, 75/35/EEC, 90/364/EEC, 90/365/ EEC and 93/96/EEC (Text with EEA relevance), OJ L 158, 30.4.2004.

${ }^{38}$ Some last even longer, in clear breach of the Schengen Borders Code, as noted by Alena Kuzko, referring to the introduction of internal borders by Germany, Austria, Denmark, Sweden, France and Norway, following the 2015 migration crisis. See Alena Kudzko, "Return to borderless Europe after COVID-19 will be difficult but not impossible”, EUR ACTIVE, March 31, 2020, available at https:/ / www.euractiv.com/section/future-eu/opinion/return-to-borderless-europe-after-covid-19-will-bedifficult-but-not-impossible/, accessed April 13, 2020.

${ }^{39}$ A similar definition of "threat to public health" is provided in the Schengen Borders Code [Article 2(21)], which allows/requires States to bar entry at external borders to third-country nationals who are considered to be a threat to public health [Article 6(1)(e)].

${ }^{40}$ See Sergio Carrera and Ngo Chun Luk, "Love thy neighbour?", 27. In the Guidelines adopted by the Commission on March 16, 2020, it is allowed that, in an extremely critical situation, a Member State can identify a need to reintroduce border controls as a reaction to the risk posed by a contagious disease. COVID-19 Guidelines for border management measures to protect health and ensure the availability of goods and essential services, C(2020) 1753 final, 16.3.2020. 
to handle the disease. States will no doubt argue that even their most restrictive measures were proportionate the scientific knowledge available at the time they were enacted. As noted in the previous section, save for blatantly disproportionate and discriminatory measures, or measures in breach of unequivocal provisions of EU law, such as the prohibition of non-refoulement, ${ }^{41}$ EU Member States will likely be able to justify much of what they have been doing in their fight against the pandemic.

Since its first communication on the topic, the European Commission has tried to curb the Member States' worst impulses, calling on them to comply with key tenets of EU law, such as ensuring mobility rights for EU citizens, respecting the principle of non-refoulement, and ensuring that restrictive border measures are necessary, proportional and non-discriminatory. The Commission's approach has been criticised for being too soft on States and ineffective in restoring freedom of movement in the Schengen Area, ${ }^{42}$ but, on a counterfactual note, it can be argued that Member States would probably have gone even further in their restrictive measures if it were not for the Commission's nudging. The Commission took upon itself the task to monitor the Member States' compliance with the principle of proportionality and to intervene to request the lifting of the measures considered disproportionate, especially when they have an impact on the Single Market. ${ }^{43}$ In the guidelines issued on March 16, 2020, the Commission explained that a decision to refuse entry at Schengen external borders would only be proportionate if taken following consultation of the health authorities and considered by them as suitable and necessary to attain the public health objective. ${ }^{44}$ In its communication of September 4, 2020, the Commission noted that the principle of proportionality required that any limitations to EU citizens' right to free movement must be necessary and genuinely meet objectives of general interest recognised by the Union or the need to protect the rights and freedom of others. ${ }^{45}$

The trail of Commission communications over the past seven months provides some insight into what the main concerns and difficulties on the ground have been. One is to ensure admission at Schengen external borders to nationals of all EU Member States and Schengen Associated States, and their family members, as well as of third-country nationals who are long-term residents under the Long-Term Residence Directives and persons deriving their right to reside from other EU Directives or national law, or who hold long-term visas. Initially, States were only asked to admit travellers returning to their homes ${ }^{46}$ but the Commission has in the

\footnotetext{
${ }^{41}$ Article 78(1) of the Treaty on the Functioning of the EU and Article 19(2) of the Charter of Fundamental Rights.

${ }^{42}$ At the time of writing, Finland, Hungary, Denmark and Norway have not yet lifted controls at their internal borders and the related travel restrictions due to COVID-19, while Austria, Denmark, France, Germany, Norway and Sweden maintain controls at their internal borders due to other causes, mostly terrorism threats. Information available at https:/ /ec.europa.eu/home-affairs/what-we-do/policies / borders-and-visas/schengen/reintroduction-border-control_en, accessed September 28, 2020. For a scathing criticism of the Commission's mimicry of the States' health scare rationale for closing borders, see Sergio Carrera and Ngo Chun Luk, "Love thy neighbour?”, 17-19.

${ }^{43}$ Joint European Roadmap towards lifting COVID-19 containment measures (2020/C 126/01), 17.04.2020.

${ }^{44}$ COVID-19 Guidelines for border management measures to protect health and ensure the availability of goods and essential services, C(2020) 1753 final, 16.3.2020.

${ }^{45}$ Proposal for a Council Recommendation on a coordinated approach to the restriction of free movement in response to the COVID-19 pandemic, $\operatorname{COM}(2020) 499$ final, 4.9.2020.

${ }^{46}$ Communication from the Commission to the European Parliament, the European Council and the Council COVID-19: Temporary Restriction on Non-Essential Travel to the EU, COM(2020)
} 
meantime recommended that these travellers be allowed to travel to the EU+ area for any purpose. ${ }^{47}$ Another major concern is to ensure that the travel restrictions at Schengen external borders do not apply to third country nationals who perform an essential function (e.g. frontier workers, transport personnel, seasonal workers in agriculture) or who are in need of international protection. ${ }^{48}$ Another is to ensure that any decision on refusal of entry to third-country nationals is, not only proportionate and non-discriminatory, but also implemented in a way that ensures full respect of the human dignity of the persons concerned, besides complying with the special provisions on the right to asylum and international protection or the issue of long-term visas. ${ }^{49}$ Also, to ensure that when deciding whether the temporary restriction on non-essential travel to the EU applies to a third-country national, residence in a third country for which the restrictions on non-essential travel have

115 final, 16.3.2020. According to the guidelines published by the Commission on the same day, this means that the Member States must always admit their own citizens and residents, and facilitate transit of other EU citizens and residents who are returning home. COVID-19 Guidelines for border management measures to protect health and ensure the availability of goods and essential services, C(2020) 1753 final, 16.3.2020.

${ }^{47}$ Possibly subject to health requirements, such as self-isolation. Communication from the Commission to the European Parliament, the European Council and the Council on the third assessment of the application of the temporary restriction on non-essential travel to the EU, $\operatorname{COM}(2020) 399$ final, 11.6.2020.

${ }^{48}$ Communication from the Commission to the European Parliament, the European Council and the Council COVID-19: Temporary Restriction on Non-Essential Travel to the EU, COM(2020) 115 final, 16.3.2020. The need to ensure the free movement of transport workers, irrespective of nationality and place of residence, was further stressed by the Commission in its Communication on the implementation of the Green Lanes under the Guidelines for border management measures to protect health and ensure the availability of goods and essential services, $\operatorname{COM}(2020) 1897$ final, 23.3.2020. The case of cross-border and seasonal workers was dealt with in the Communication from the Commission Guidelines concerning the exercise of the free movement of workers during COVID-19 outbreak, C(2020) 2051 final, 30.3.2020, and later in the Communication from the Commission Guidelines on seasonal workers in the EU in the context of the COVID-19 outbreak, C(2020) 4813 final, 16.7.2020. The case of seafarers was dealt with in the Communication from the Commission Guidelines on protection of health, repatriation and travel arrangements for seafarers, passengers and other persons on board ships, C(2020) 3100 final, 8.4.2020. On May 13, 2020, the Commission returned to the case of essential workers, noting that significant problems still remain for the crossing of certain internal borders and calling on Member States to allow workers, in particular transport, frontier, posted and seasonal workers, and service providers to cross borders and have unhindered access to their place of work. Communication from the Commission COVID-19 Towards a phased and coordinated approach for restoring freedom of movement and lifting internal border controls, C(2020) 3250 final, 13.05.2020. On June 11, the Commission recommended that the list of travellers with an essential function extended to include also people travelling for the purpose of study and highly qualified third-country workers if their employment is necessary from an economic perspective and the work cannot be postponed or performed abroad. Communication from the Commission to the European Parliament, the European Council and the Council on the third assessment of the application of the temporary restriction on nonessential travel to the EU, COM(2020) 399 final, 11.6.2020.

49 Communication from the Commission COVID-19 Guidance on the implementation of the temporary restriction on non-essential travel to the $\mathrm{EU}$, on the facilitation of transit arrangements for the repatriation of EU citizens, and on the effects on visa policy, C(2020) 2050 final, 30.3.2020. On April 17, 2020, the Commission issued separate guidelines on asylum, stressing the need to ensure that access to the asylum procedure continues to the greatest extent possible during the COVID-19 pandemic, and encouraging States to resume transfers, resettlement-related activities and return procedures as soon as practically possible in view of the evolving circumstances. Communication from the Commission COVID-19: Guidance on the implementation of relevant EU provisions in the area of asylum and return procedures and on resettlement, C(2020) 2516 final, 17.4.2020. 
been lifted should be the deciding factor, and not nationality. ${ }^{50}$ To ensure that the visa holders who are unable to leave the territory due to travel restrictions are not penalised for overstaying their visas, with the Commission recommending that States issue them with long-stay visas or with temporary residence permits, and that they waive administrative sanctions or penalties on individuals in those circumstances. ${ }^{51}$ To ensure that EU citizens stranded in Member States other than their State of nationality, in third countries or on the High Seas, and their family members, are able to return home - if necessary, with the repatriation assistance of the Commission, the European External Action Service and the EU Delegation in the third country and that Member States facilitate their onward transit by any means of transportation available. ${ }^{52}$ To ensure that the absence of the necessary visas or the expiry of travel documents does not hinder the disembarkation of third-country nationals on humanitarian grounds and to facilitate repatriation, nor the right of EU citizens to enter the territory of a Member State different from that of their nationality..$^{53}$ To ensure that travel restrictions and border controls are lifted once the border regions' epidemiological situation converges sufficiently and social distancing rules are widely and responsibly applied, and that the gradual re-opening of borders gives priority to cross-border and seasonal workers and avoids any discrimination against EU mobile workers. $^{54}$

\section{Conclusion: the perks of being an EU citizen}

European Union citizenship does not bestow an abundance of rights upon its holders, but it grants them the fundamental right to move and reside freely within the territory of the Member States [Article 45(1) of the EU Charter of Fundamental Rights]. As noted earlier, this right may be restricted on public health grounds under Articles 27 to 29 of Directive 2004/38/EC, and Member States have been making ample use of this possibility in their response to the COVID-19 pandemic. When Italy became the epicentre of the outbreak in early March 2020, the sudden and unilateral

\footnotetext{
${ }^{50}$ Communication from the Commission to the European Parliament, the European Council and the Council on the third assessment of the application of the temporary restriction on non-essential travel to the EU, $\operatorname{COM}(2020) 399$ final, 11.6.2020.

${ }^{51}$ Communication from the Commission COVID-19 Guidance on the implementation of the temporary restriction on non-essential travel to the $\mathrm{EU}$, on the facilitation of transit arrangements for the repatriation of EU citizens, and on the effects on visa policy, C(2020) 2050 final, 30.3.2020.

${ }^{52}$ Communication from the Commission COVID-19 Guidance on the implementation of the temporary restriction on non-essential travel to the EU, on the facilitation of transit arrangements for the repatriation of EU citizens, and on the effects on visa policy, C(2020) 2050 final, 30.3.2020. In its Communication of March 23, 2020, on the implementation of green lanes, the Commission had already urged Member States to set up safe passage transit corridors for all EU citizens being repatriated, regardless of their nationality, and to ensure that they have at least one airport functional for repatriation and international relief flights. The repatriation and travel arrangements for seafarers, passengers and other persons on board ships were the object of the Communication from the Commission Guidelines on protection of health, repatriation and travel arrangements for seafarers, passengers and other persons on board ships, C(2020) 3100 final, 8.4.2020.

${ }^{53}$ Communication from the Commission Guidelines on protection of health, repatriation and travel arrangements for seafarers, passengers and other persons on board ships, C(2020) 3100 final, 8.4.2020. ${ }^{54}$ Joint European Roadmap towards lifting COVID-19 containment measures (2020/C 126/01), 17.04.2020. The need to ensure proportionality and non-discrimination among EU citizens when lifting internal borders was reiterated in the Communication from the Commission COVID-19 Towards a phased and coordinated approach for restoring freedom of movement and lifting internal border controls, C(2020) 3250 final, 13.05.2020.
} 
reintroduction of border controls within the Schengen Area left many EU citizens stranded, barred from accessing their places of work and/or residence. Restoration of freedom of movement within the Schengen Area and protection of EU citizens' mobility rights have been a top priority for the European Commission, since its first communication on travel restrictions in the context of the COVID-19 pandemic, of March 16, 2020, even though the primary goal was to prevent the knock-on effects of the mobility restrictions on the Internal Market. Frequent reminders by the Commission of the need to ensure that EU citizens are not discriminated against on the basis of their nationality and that they are not hindered by disproportionately restrictive measures suggest that EU citizens (in particular cross-border and seasonal workers $)^{55}$ are still facing serious travel restrictions and discriminatory treatment on the ground. With Member States' nationalistic responses, it is national citizenship not EU citizenship - that secures individuals' admission to the territory, even if there have been cases - blatantly illegal vis-à-vis the ECHR and EU law - of EU Member States (e.g. Cyprus) barring admission to their own nationals.

Where the perks of EU citizenship really showed was in the repatriation from third countries, where EU citizens were able to benefit from the diplomatic and consular protection of Member States other than their State of nationality, under Article 46 of the EU Charter of Fundamental Rights. The joint action of the Commission and the Member States in securing assistance and consular repatriation operations to EU citizens stranded in third-countries allowed thousands to return home ${ }^{56}$ and demonstrated how a key entitlement of EU citizenship can be put into effect at crucial junctures. An arguable silver lining in this whole nightmarish process.

\footnotetext{
${ }^{55}$ See Communication from the Commission Guidelines on seasonal workers in the EU in the context of the COVID-19 outbreak, C(2020) 4813 final, 16.7.2020.

${ }^{56}$ Detailed information on repatriation operations by country is available at https://eeas.europa.eu/ headquarters/headquarters-homepage/76203/good-stories-consular-support-eu-citizens-strandedabroad_en, accessed April 15, 2020.
} 